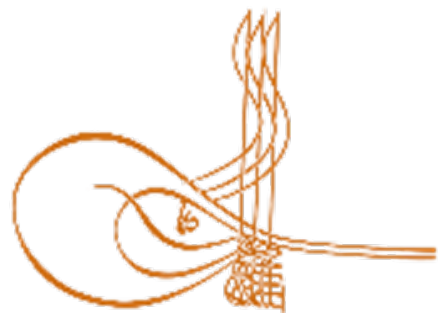

www.turkishstudies.net/education
TurkishStudies-EducationalSciences

eISSN: $2667-5609$

ResearchArticle / Araștırma Makalesi

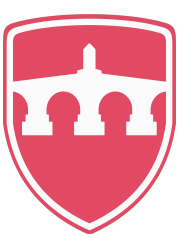

INTERNATIONAL BALKAN

UNIVERSITY Sponsoredby IBU

\title{
Ebeveynlik ve Çocuk Cinselliği Anketi’nin Türkçe Uyarlaması: Geçerlik ve Güvenirlik Çalışması
}

\author{
The Adaptation of Parentingand Child Sexuality Questionnatre into Turkish: A Validity \\ and Reliability Study
}

\author{
Seda Donat Bacıoğlu ${ }^{*}$ Dilber Tezel ${ }^{* *}$
}

\begin{abstract}
The most important sources of information about sexuality of children are their parents. Thepurpose of this study to adapt Parenting and Child Sexuality Questionnaire to Turkish. After language equivalance studies, the questionnaire was administered to 322 parents who have a child aged between 3-14 years. The questionnaire consists of five scales which their names "Parents' Knowledge and Experiences of Sexual Education", "Parenting Strategies", "Parental Self-Assessment", "Parents' Views on The Importance of Sex Education", "Parental Opinions about Child Sex Education Cirriculum" and includes open-ended questions. In order to analyses the data, factor analyses, Cronbach alpha correlation coefficients, corrected item-total correlations and t-tests between items were used. According to the results; from the five scales in the questionnaire, it was seen that 3 scales formed a single-factor structure that overlaps with the original scale structure, and two scales were obtained with a three-factor structure unlike the original scale structure. The fit index values of the scales showed acceptable and good fit values. The internal consistency coefficients of the scales were respectively $.65, .91, .90, .76, .82$, and .90 . As a result, this questionnaire can be used by experts who want to research on the roles of parents on sexual education programs for child sexual development.
\end{abstract}

Structured Abstract: Problem: Parents are responsible for monitoring and supporting the mental, physical, emotional, social and sexual development of the child from birth. Supporting sexual development includes the ability of children to receive appropriate sexual education for their age. Sexual education is a lifelong process of obtaining information, attitudes, beliefs and values, and includes all of the roles of sexual roles, interpersonal relationships, love, privacy, body perception and reproductive health (Elikü̧̈ükand Sönmez, 2011). The results of the researches indicate that parents do not know how to talk about sexuality with their

*Dr. Öğr. Üyesi, Trakya Üniversitesi, Eğitim Fakültesi, Rehberlik ve Psikolojik Danışmanlık Anabilim dalı Assistanf Prof. Dr., Trakya University, Faculty of Education, Guidance \& Counseling Department

ORCID 0000-0001-9901-0601

sedadonatbacioglu@trakya.edu.tr

** Dr. Öğr. Üyesi, Trakya Üniversitesi, Eğitim Fakültesi, Özel Eğitim Bölümü

Asst. Prof. Dr., Trakya University, Faculty of Education, Special Education Department

ORCID 0000-0003-3151-5739

dilbertezel@trakya.edu.tr

Cite as/ Atıf: Donat Bacıoğlu, S. \& Tezel, D. (2020). Ebeveynlik ve çocuk cinselliği anketi: Türkçe uyarlaması,

geçerlik ve güvenirlik çalışması, TurkishStudies - Education, 15(1), $79-90$ https://dx.doi.org/10.29228/TurkishStudies.40121

Received/Geliş: 11 December/Aralık 2019

Accepted/Kabul:25 February/Şubat 2020

Copyright à INTAC LTD, Turkey 
children and that they feel inadequate in providing sexual education (Erbil vd., 2010; Eliküçük ve Sönmez, 2011; Konur, 2006; Tuğrul ve Artan, 2001. However, sexuality that begins with birth, healthy part of life and children need to receive sexual education in the family environment.

Method: Children have the right to information about sexuality. In order to provide sexual education, there is a need for evidence-based programs to support parents. Such programs should ideally be based on theoretical and empirical literature on parent-child communication. The aim of this study was to adapt the Parenting and Child Sexuality Questionnaire developed by Morawsko et al. (2015) to Turkish. The questionnaire consists of five scales which their names " Parents' Knowledge and Experiences of Sexual Education", "Parenting Strategies", "Parental Self-Assessment", " Parents' Views on The Importance of Sex Education", "Parental Opinions about Child Sex Education Cirriculum" and includes open-ended questions. After examining and confirming equivalency between English and Turkish versions, the scale was administered to 322 parents who have a child aged between 3-14 years. In order to examine validity and reliability of the questionnaire, factor and item analyses; Cronbach alpha correlation coefficients, corrected item-total correlations and t-tests between items were used.

Findings: Resultsshowed that there was a high positive and significant relationship between the English and Turkish forms of the questionnaire $(\mathrm{r}=.80, \mathrm{r}=.80, \mathrm{r}=.82, \mathrm{r}=.81, \mathrm{r}=.83, \mathrm{r}=.65 ; \mathrm{p}<0.05)$. According to the factor analyses results of five likert-type scales in the questionnaire, it was seen that 3 scales formed a single-factor structure that overlaps with the original scale structure, and two scales were obtained with a three-factor structure unlike the original scale structure. CFA results were; the first scale showed RMSEA $=0.06$ acceptable fit, GFI $=0.99$ good fit, CFI $=0.98$ good fit and AGFI $=0.95$ good fit; $2 . n d$ scale showed RMSEA $=0.09$ acceptable fit, GFI $=0.90$ acceptable fit, CFI $=0.95$ good fit, and AGFI $=0.85$ acceptable fit; 3rd scale had good fit RMSEA $=0.01$, good fit GFI $=0.99$, good fit CFI $=0.98$ and good fit AGFI $=0.99$; The 4th scale showed RMSEA $=0.08$ acceptable fit, GFI $=0.97$ good fit, CFI $=0.98$ good fit and $\mathrm{AGFI}=0.93$ good fit; the 5 th scale showed RMSEA $=0.07$ acceptable fit, GFI $=0.91$ acceptable fit, CFI $=0.97$ good fit and AGFI $=0.88$ acceptable fit. The internal consistency coefficients of the scales indicate that reliability is sufficient ( $\alpha=.65, \alpha=.91$ and $\alpha=.90, \alpha=.76, \alpha=.82, \alpha=.90$, respectively).

Results and Discussion: The validity and reliability of the questionnaire is thought to be used by researchers who examine the parenting roles in the child's sexual development and sexual education programmes for children sexual development.

Keywords: Sexual Education, Children, Sexuality, Parents, Parenting Strategies

Öz: Çocukların, cinsellik hakkında en önemli bilgi kaynakları ebeveynleridir. Bu çalışmanın amacı, Morawsko ve arkadaşlarının (2015) geliştirdikleri Ebeveynlik ve Çocuk Cinselliği Anketini Türkçe’ye uyarlamaktır. Türkçe form, dil geçerliği sınamasının ardından Edirne ilinde yaşayan 3-14 yaş arası çocuk sahibi olan toplam 322 aileye uygulanmıştır. Araştırmada, veri toplamak amacıyla, Ebeveynlik ve Çocuk Cinselliği Anketi kullanılmıştır. Anketin içeriğinde, "Ebeveynlerin Cinsel Eğitim Bilgi ve Deneyimleri", "Ebeveynlik Stratejileri”, "Ebeveyn Öz-Değerlendirme”, "Ebeveynlerin Cinsel Eğitimin Önemi ile ilgili Görüşleri”, "Cinsel Eğitim Programı Müfredatı Hakkında Ebeveynlerin Görüşleri” olmak üzere toplamda 5 tane farklı derecelendirme ölçeği ve açık-kapalı uçlu sorular bulunmaktadır. Nicel verilerin analizinde, ölçeklerin yap1 geçerliğini incelemek üzere faktör analizi ve madde analizi yapılmış; güvenirlik için Cronbach alfa iç tutarlılık katsayıları, düzeltilmiş madde korelasyonları ve t testi kullanılarak alt-üst \% 27'lik grupların madde ortalamaları arasındaki farkların anlamlılığı incelenmiştir. Yapılan analizlerin sonucunda, 3 ölçekte tek faktörlü yap1 ortaya çıkarken, 2 ölçekte 3 faktörlü yap1 ortaya çıkmıştır. Ölçeklerin uyum indeksleri kabul edilebilir ve iyi seviyede uyum değerlerini göstermiştir. Ölçeklere ait alfa iç tutarlılık katsayıları sırasıyla; .65, .91, .76, .82 ve .90 olarak hesaplanmıştır. Sonuç olarak, geçerlik ve güvenirlik çalışması yapılan bu anketin, çocuğun cinsel gelişiminde ebeveynlerin rollerini incelemek ve cinsel eğitim programları hazırlayıp geliştirmek üzerine araştırma yapmak isteyen uzmanlar tarafından kullanılabileceği düşünülmektedir.

Anahtar Kelimeler: Cinsel Eğitim, Çocuk, Cinsellik, Ebeveyn, Ebeveynlik Stratejileri 


\section{Giriş}

Kişinin sağlıklı bir yaşam sürmesinin temelleri çocukluk yıllarında atılmaktadır. Çocukların doğumundan itibaren zihinsel, bedensel, duygusal, sosyal ve cinsel gelişim süreçlerini takip etme ve bilinçli bir şekilde desteklemede ebeveynlerin sorumlulukları büyüktür. Cinsel gelişimi destekleme, çocukların yaşına uygun cinsel eğitimi alabilmelerini de kapsamaktadır. Cinsel eğitim, bireyin fiziksel, duygusal ve cinsel gelişimini anlaması, olumlu bir kişilik kavramı geliştirmesi, insan cinselliğine, başkalarının haklarına, görüş ve davranışlarına saygılı bir bakış açısı edinmesi ve olumlu davranış biçimi, değer yargıları geliştirmesi eğitimidir şeklinde tanımlanabilir (Bayhan ve Artan, 2004). Cinsel eğitim, yaşam boyu süren bilgi alma, tutum, inanç ve değerler kazanma sürecidir ve cinsel roller, kişiler arası ilişkiler, sevgi, mahremiyet, vücut algısı ve üreme sağlığı konularının hepsini kapsamaktadır (Eliküçük ve Sönmez, 2011). Çocukların büyüme ve gelişme süreçleri boyunca cinsellikle ilgili pozitif bilgi almaları ve cinselliğe yönelik olumlu bakış açısı oluşturmaları için, aile içinde başlayan cinsel eğitimin, çocukların ve gençlerin büyük bir çoğunluğuna toplu ulaşma fırsatı sağlayan, okullarda verilmesi ve cinsel eğitimin kurumsallaşması gerekmektedir. Aksi takdirde cinsel eğitimin önemli bir kısmı informal biçimde bir başka değişle "sokakta" gerçekleşecek ve istenmedik sağlık sorunlarının ortaya çıkması da kaçınılmaz olacaktır (Gürsoy ve Gençalp 2010).

Çocukların sağlıklı bir kişilik geliştirebilmeleri için cinsiyetlerinin değerli olduğunu bilmeleri gerekir. Anne ve babalar çocuklarıyla vücutları ve cinsel gelişimleri hakkında konuştukları zaman çocuklar, cinselliğin aile ile konuşulabileceğinin farkına varırlar. Ailelerin çocuklarına cinsel konularda verdiği bilgiler onların kendilerini sağlıklı ve normal hissetmelerine ya da suçlu ve kötü hissetmelerine sebep olabilir (Semerci, 2009). Bu konuda yapılan araştırmalar, çocuğun cinsel eğitiminde ebeveynlerin ihtiyaçlarını ortaya koymaktadır (Erbil vd., 2010; Eliküçük ve Sönmez, 2011; Konur, 2006; Tuğrul ve Artan, 2001). Eroğlu ve Gölbaş1 (2005) tarafından bir lisede, ebeveynlerin cinsellikle ilgili konularda ebeveynlerin çocuklarıyla olan iletişimleri ve yaşadıkları durumları belirlemek amacıyla yapılan çalışmanın sonucunda, ebeveynlerin \%36.3'ünün çocuklarının cinsellikle ilgili sorularını yanıtlarken kendilerini bilgi yönünden yetersiz hissettikleri saptanmıştır. Ayrıca ebeveynlerin \%37.6'sının cinsellikle ilgili konuları çocuklarıyla rahat bir şekilde konuşamadıkları, tamamına yakınının profesyonel bir kişi ve merkezden yardım almadığ $\breve{1}_{1}$ ve çocuklarını konu ile ilgili profesyonel kişi ya da kuruma yönlendirmedikleri belirlenmiştir. Oysaki doğumla birlikte başlayan cinsellik, yaşamın doğal, sağlıklı bir parçasıdır ve çocukların ilk cinsellik eğitimini aile ortamında almaları gereklidir (Eliküçük ve Sönmez, 2011).

Türkiye'deki cinsel sağlık eğitimi çalışmaları genel olarak üniversitelerce ve bazı kurum/ sivil toplum kuruluşları tarafindan yürütülmekte, okullarda bu tür bir eğitim verilmemektedir (Ersoy, 2014). Anne-babaların, çocukların ilk cinsel eğitimcileri olarak hem ilk cinsel bilgileri verme ve model olmaları için hem de okuldan cinsel eğitim talep etme, verilen eğitime destek olma, verilen eğitimin bir parçası olma ve verilen eğitimi denetleme fonksiyonları olmalıdır (Çalışandemir, Bencik ve Artan, 2008).

Özetle, çocukların cinsellik hakkında bilgi edinme hakkı vardır. Cinsel eğitimin verilebilmesi için de ebeveynlere destek olacak kanıta dayalı programlara ihtiyaç vardır. Bu tür programlar ideal olarak ebeveyn-çocuk iletişimi hakkındaki teorik ve ampirik literatüre dayanmalidir (Byers, Sears ve Weaver 2008; Pluhar, DiIorio ve McCarty 2008). Morowska (2015)'ya göre bu tür programların geliştirilmesi için, çocukların cinselliği ile ilgili ebeveyn görüşleri, ebeveyn davranışlarının öngörücüleri ve çocuğunu cinsellik hakkında eğitmede güven ve ebeveynlerin müdahale tercihleri hakkında bilgiye ihtiyaç vardır. Ulusal literatür incelendiğinde bu tür bilgileri bir arada edinmeyi sağlayan bir ölçme aracına rastlanmamıştır. $\mathrm{Bu}$ nedenle araştırmanın amacı; Morawska ve arkadaşları (2014) tarafından geliştirilen Ebeveynlik ve Çocuk Cinselliği Anketi'nin Türk ebeveynlerden oluşan bir örneklemde geçerliliği ve güvenilirliğinin 
incelenmesidir. $\mathrm{Bu}$ uyarlamanın, çocuk cinsel eğitimi konusunda yapılacak çalışmalarda, araştırmacıların kullanımına sunulması açısından önemli bir katkı sağlayacağı düşünülmektedir.

\section{Yöntem}

\section{Araştırma Örneklemi}

Araştırmanın evreni Edirne ili merkezinde yaşayan 3-14 yaş aralığında çocuk sahibi olan anne-babalar oluşturmaktadır. Araştırmanın örneklemini ise; rastgele örnekleme yöntemiyle seçilen, gönüllü katılan 322 anne-baba oluşturmaktadır. Eğer aileler, bu yaş grubunda birden fazla çocuğa sahipseler, çocuklardan birini düşünerek anketi cevaplandırmaları istenmiştir.

\section{Veri Toplama Aracı}

Araştırmada, veri toplamak amacıyla, Ebeveynlik ve Çocuk Cinselliği Anketi kullanılmıştır. Bu anket, Morawska ve arkadaşları (2015) tarafından geliştirilmiş olup, çocuğun cinsel gelişiminde ebeveynlerin önemli bir role sahip oldukları düşüncesinden yola çıkarak, içeriğindeki sorularla şunları ölçmeyi amaçlamaktadır: (1) ebeveynlerin görüşlerini ve çocuklarıyla cinsellik ile ilgili iletişim kurma konusundaki güveni incelemek, (2) ebeveynlerin öz-yeterliliğini yordayan faktörleri keşfetmek, (3) çocuğa verilecek cinsel eğitim programı içeriği için ebeveyn tercihlerini değerlendirmektir (Morawska ve ark., 2014). Bu amaçları gerçekleştirmeye yönelik anket kapsamında; beş adet derecelendirme ölçeği, dört adet kapalı uçlu soru ve üç adet boşluk doldurulan açık uçlu soru bulunmaktadır.

İlk soru grubu, ebeveynin cinsel eğitim bilgilerini ve deneyimlerini incelemektedir. Toplamda altı soru maddesi bulunmaktadır. Bunlardan dört madde, ebeveynlerin çocuk cinselliği ve çocuklarına cinsel eğitim vermek-almak konularında ne kadar yeterli bilgi sahibi olup olmadığını; diğer iki madde ise, ebeveynlerin cinsellik hakkında görüşürken kendini rahat hissedip hissetmediğini 0-3 arasında derecelendirmesinden oluşmaktadır. İç tutarlılık katsayısı .77 olarak hesaplanmıştır. Ebeyenlerden ayrıca kendi çocukluklarında cinsellikle ilgili bilgi kaynakları, şu anki bilgi kaynakları ve çocuklarının cinsel gelişimi ile ilgili bilgi kaynaklarının neler olduğu ve çocuğuyla cinsellik konusunda nasıl konuştuğu ile ilgili açık uçlu sorulara cevap vermeleri istenmektedir.

İkinci soru grubu, ebeveynlik stratejileri ile ilgilidir. Bu kısımda toplam 17 tane madde bulunmaktadır ve iki aşamalı olarak cevaplanmaktadır. İlk aşamada, son dört hafta içinde ebeveynin çocuğu ile cinsellik hakkında konuşurken kullandığı iletişim tekniklerini 0-3 arasında derecelendirmesi gerekmektedir. İkinci aşamada ise, ebeveynin her bir durum için-o durum nadiren ya da hiç ilgili olmasa bile- kendinden emin olma düzeyini (1-10 arası) derecelendirmesinden oluşmaktadır. Örneğin, "Çocuğum cinsellikle ilgili bir soru sorduğunda sessiz kaldım" maddesinde, aynı form üzerinde hem son dört haftayı düşünerek derecelendirmesi hem de böyle bir durum yaşandığında kendinden ne kadar emin olduğunu 1'den (kesinlikle yapamam) 10'a ( kesinlikle yaparım) kadar derecelendirmesi beklenmektedir. Anketlerin iç tutarlılık katsayısı .90 ve .95 olarak hesaplanmıştır. Ayrıca ebeveynlerin çocuğunun cinsellikle ilgili sorularına cevap verirken ebeveynin kendini nasıl hissettiğini- bilgili, emin, rahat ve kaygıl1- 1-5 arası derecelendirdiği bir öz-değerlendirme kısmı bulunmaktadır $(\alpha=.78)$. Bu grubu tamamlayıcı olarak ebeveynlerden, çocuğunun cinsellikle ilgili bilgiyi nereden aldığ açık uçlu sorusuna çoklu seçenekler içerisinden işaretlemesi beklenmektedir.

Son soru grubu, ebeveynlerin cinsellik hakkında çocuklarını eğitmenin ne düzeyde önemli olduğuna dair görüşlerini (5 madde) ve çocukları eğitmeye yardımcı olmak amacıyla ne tür bilgilerin yararlı olduğuna dair görüşlerini (22 madde) 1-5 arasında derecelendirmelerini istemektedir. Anketlerin iç tutarlılık katsayısı .65 ile .94 olarak hesaplanmıştır. Ebeveynlere son olarak; çocuklarıyla cinsellik hakkında nasıl konuşmayı kolaylaştırıcı neler yaptığı ve çocuklarının cinsel gelişimini desteklemede aile becerilerini geliştirmeye yönelik anne-baba programının 
içeriğine eklemek istediklerini açık uçlu sorarak boşluk kısmına yazmaları istenmektedir. Sonuç olarak; Ebeveynlik ve Çocuk Cinselliği Anketi, "Ebeveynlerin Cinsel Eğitim Bilgi ve Deneyimleri", "Ebeveynlik Stratejileri”, "Ebeveyn Öz-Değerlendirme", "Ebeveynlerin Cinsel Eğitimin Önemi ile ilgili Görüşleri”, "Cinsel Eğitim Programı Müfredatı Hakkında Ebeveynlerin Görüşleri” olmak üzere toplamda 5 tane farklı ölçeğin, 4 tane kapalı uçlu ve 3 tane açık uçlu soruların bir araya gelmesinden oluşmaktadır.

\section{Verilerin Toplanması}

Araştırma öncesinde, ölçme aracını kullanmak üzere geliştiren araştırmacılardan izin alınmış olup, ebeveynlere uygulamak için de üniversite etik kurulundan gerekli izinler alınmıştır. Araştırma formların dağıtım ve toplanma süreci 2016-2017 yılları arasında gerçekleştirilmiştir. Araştırmacılar, aileleri bilgilendirip, gönüllü katılımlarının onayını aldıktan sonra anketler uygulanmıştır. Görüşme ve uygulama süresi toplam 30-40 dakika sürmektedir.

\section{İşlemler}

Anketin Türk ebeveynlerden elde edilen nicel verilerinin faktör yapısını incelemek amacıyla açımlayıcı faktör analizi, doğrulayıcı faktör, madde analizi kullanılmıştır. İlk olarak, faktör analizi için örneklem yeterliliğini belirlemek üzere KaiserMeyerOlkin (KMO) katsayısı ve Barlett (Sphericity) Küresellik testi yapılmıştır. KMO'nun .60'ın üstünde çıkması ve Barlett testinin manidar çıkması verilerin açımlayıcı faktör analizi için uygunluğunu göstermektedir (Büyüköztürk, 2006).

Açımlayıcı faktör analizi, çok sayıda değişkenden (maddeden) bu değişkenlerin birilikte açıklayabildikleri az sayıda tanımlanabilen anlamlı yapılara ulaşmayı hedefler (Büyüköztürk, 2006). Açımlayıcı faktör analizinde, ölçekte yer alan bir maddenin tanımlanacak olan bir faktörde yer alıp almaması, o faktörle olan ilişkisini gösteren yük değerinin yüksek olmasına bağlıdır. Madde faktör yük değerinin genellikle 0.45 ve daha yüksek olması istenmekle birlikte faktör yük değeri 0.30 olan maddeler de ölçekte tutulabilir (Erkuş, 2012). Bu çalışmada, ölçeklerin faktör yapılarını incelemek amacıyla ilk olarak döndürülmemiş temel bileşenler analizi uygulanmış, analiz daha sonra faktörleri yorumlamada ve anlamlandırmada kolaylık sağlamak amaciyla varimax dik döndürme tekniği kullanılarak tekrar edilmiştir. Ölçeklerin her birinde yer alan her bir maddenin, ölçmek istediği özelliği ölçüp ölçmediği ve ölçtükleri özellik açısından kişileri ayırt etmede yeterli olduklarının belirlenmesi amacıyla madde toplam korelasyonuna, anketten çıarılmaları halinde alfa değerlerine etkisine ve alt-üst \%27'lik gruplar arası $t$ testine bakılmıştır. Elde edilen " $t$ " değerlerinin 1.96'dan büyük olması durumunda faktörler ile ilgili maddeler arasında istatistiksel olarak anlamlı bir ilişkinin olduğu kabul edilmektedir. Çalışmanın madde analizleri ve AFA için SPSS program kullanılmıştır.

Özgün anketin yapısının Türk kültüründe ne derece geçerli olduğunu değerlendirmek amacıyla Doğrulayıcı Faktör Analizi (DFA) yapılmıştır. DFA, kuramsal bir temelden destek alarak pek çok değişkenden oluşturulan faktörlerin gerçek verilerle ne derece uyum gösterip göstermediğini değerlendirmeye yönelik bir analizdir (Sümer, 2000). Bu çalışmada DFA için Lisrel programı kullanılmıştır. Ölçeklerin güvenirliğini belirlemek için Cronbach alfa iç tutarlılık katsayısına bakılmıştır. Ebeveynlik ve Çocuk Cinselliği Anketinin içeriğinde altı farklı anketin olması nedeniyle geçerlik ve güvenirlik çalışmalarına ilişkin bulgular her bir ölçek için ayrı alt başlıklar halinde verilmiştir.

\section{Bulgular}

Dil ve kapsam geçerliliği: Araştırmanın ilk aşamasında, Türkçe'ye uyarlama çalışmaları için Ebeveynlik ve Çocuk Cinselliği Anketini (Parentingand Child SexualityQuestionnaire) geliştiren Avusturalya Queensland Üniversitesi Psikoloji bölümü ile gerekli yazışmalar yapılarak Alina Morawska'dan izin alınmıştır. Anketin İngilizce orijinalinde yer alan ifadeler, rehberlik ve 
psikolojik danışmanlık alanından 2 akademisyen, İngilizce Öğretmenliği bölümünden mütercim tercümanlık yapan bir akademisyen ve Türkçe Öğretmenliği bölümünden bir akademisyen olmak üzere dört kişilik uzman grubunun önerileri dikkate alınarak Türkçe'ye çevrilmiştir. İngilizce orijinal form ile Türkçe'ye çevrilmiş form arasında farklılı̆̆ın olup olmadığını test etmek üzere her iki dile de hakim yirmi bir akademisyene 3 hafta arayla uygulanmıştır. Anketlerin her birinden elde edilen verilerin korelasyon katsayıları SPSS programı kullanılarak karşılaştırılmış, ölçüm değerleri bakımından Türkçe ve İngilizce formları arasında istatistiksel olarak pozitif yönde anlamlı bir ilişki olduğu görülmüsstür $(\mathrm{r}=.80, \mathrm{r}=.80, \mathrm{r}=.82, \mathrm{r}=.81, \mathrm{r}=.83, \mathrm{r}=.65 ; \mathrm{p}<0.05)$. Bulgular, anketin Türkçe formunun, orijinal İngilizce formuna eş değer olduğu göstermektedir.

Ebeveynlerin Cinsel Eğitim Bilgi ve Deneyimleri Ölçeğine ait geçerlik ve güvenirlik çalışması bulguları: Ölçekte 6 madde bulunmaktadır. Ölçeğin KMO testi katsayısı .68, Barlett küresellik testinin de manidar $\left(x^{2}=397.799, s d=15, p<0,01\right)$ olduğu belirlenmiştir. Örneklem yeterliliği karşılandıktan sonra temel bileşenler analizi varimax döndürme tekniği kullanılarak yapılan AFA sonucunda, öz değeri 1'den büyük olan 2 faktörlü yap1 bir yap1 elde edilmiştir. Maddelerin aldıkları faktör yükü ve varyans değerleri birinci faktör için 2.320 ve \% 38.66, ikinci faktör için 1.278 ve \% 21.29'dir. İki faktörde toplanan maddelerin açıkladığ 1 toplam varyans miktarı \% 59.962'dir. Birinci faktör altında 2, 4, 5 ve 6. maddeler yer almaktadır ve "Bilgi" olarak adlandırılmıştır. İkinci alt boyutta 1. ve 3.maddeler yer almaktadır ve "Deneyim" olarak adlandırılmıştır. İki faktörlü bu yapı özgün ölçeğin yapısıyla tam olarak örtüşmektedir. Ölçeğin ayırtedicilik seviyesi için hesaplanan madde toplam korelasyon katsayısı $0.238-0.498$ aralığında değişmektedir. Madde toplam korelasyon katsayısının hangi ölçütün altında güvenirliğinin yetersiz sayılacağ 1 konusunda literatürde belirli bir standart değer bulunmamaktadır. Bazı kaynaklarda .30'un üzerinde olması gerektiği belirtilmekte ancak bazı araştırmacıların .20'yi sınır değer olarak aldığ1 ifade edilmektedir (Gözüm ve Aksayan, 2002). Bu araştırmada, güvenirlik ölçütü için .20 değeri esas alınmış olmakla birlikte korelasyon değeri düşük olan madde çıkarıldığında alfa katsayısındaki değişime bakılarak karar verilmesi gerektiğine (Kalayc1, 2005; Özdamar, 2004) istinaden düşük korelasyonlu iki madde (madde 1 ve madde 3) çıkarıldığında Cronbach alfa değeri değişmediğinden ve orijinal ölçeğe bağlı kalınması gerektiği vurgulandığından (Gözüm ve Aksayan, 2002) bu maddeler ölçekten çıkarılmamıştır. Faktörler ile ilgili maddeler arasında istatistiksel olarak anlamlı bir ilişkinin olup olmadığı t testi sonucunda ise anlamlı bir ilişki saptanmıştır. Elde edilen bulgulara ilişkin sonuçlar Tablo 1'de gösterilmiştir.

Tablo 1: Ebeveynlerin Cinsel Eğitim Bilgi ve Deneyimleri Ölçeğine ait bulgular

\begin{tabular}{|c|c|c|c|c|c|c|}
\hline \multicolumn{2}{|c|}{ Maddeler } & f1 & $\mathrm{f} 2$ & Madde toplam & $\begin{array}{l}\text { Madde silinmesi } \\
\text { ar }\end{array}$ & $t$ değeri \\
\hline \multirow[t]{4}{*}{ Bilgi } & $\mathrm{md} 4$ & .781 & & .497 & .570 & $12.39^{*}$ \\
\hline & md6 & .772 & & .492 & .566 & $11.50 *$ \\
\hline & $\mathrm{md} 2$ & .765 & & . 457 & .591 & $11.62 *$ \\
\hline & $\mathrm{md} 5$ & .713 & & .498 & .561 & $10.53 *$ \\
\hline \multirow[t]{2}{*}{ Deneyim } & $\mathrm{md} 3$ & & .836 & .279 & .681 & $2.68^{*}$ \\
\hline & $\mathrm{md} 1$ & & .736 & .238 & .667 & $2.92 *$ \\
\hline \multicolumn{2}{|c|}{$\begin{array}{c}\text { Açılanan varyans (\%) } \\
\text { Toplam }=\% 59.962\end{array}$} & 38.66 & 21.29 & & & \\
\hline
\end{tabular}

AFA sonucu tespit edilen 2 faktörlü yapının doğrulanması amacıyla Doğrulayıc1 Faktör Analizi (DFA) uygulanmış̧ır. Modele iliş̧in faktör yükleri Şekil 1'de gösterilmiştir (bkz.ek 1). Şekilde görüldügüü üzere maddelerin faktör yükleri 0.34 (madde 3) ile 0.77 (madde 1) arasında değişmektedir ve bütün faktör yükleri istatistiksel olarak anlamlıdır. DFA ile sınanan modelin uyum indeksleri incelendiğinde ki-kare değerinin serbestlik derecesine oranının $\left(\mathrm{x}^{2} / \mathrm{df}=2.290\right)$ 3'ün altında iyi uyum olduğu görülmüştür. Diğer uyum indeksleri incelendiğinde, RMSEA= 0.06 $(0.05<$ RMSEA $<0.10)$ kabul edilebilir uyum. GFI $=0.99(0.95<\mathrm{GFI}<1)$ iyi uyum. $\mathrm{CFI}=0.98$ $(0.95<\mathrm{CFI}<1)$ iyi uyum ve $\mathrm{AGFI}=0.95(0.90<\mathrm{AGFI}<1)$ iyi uyum gösterdiği görülmektedir. 
Kurulan modelin boyutlarının güvenirliklerini incelemek amacıyla Cronbach alfa değerleri hesaplanmıştır. Elde edilen sonuçlara göre, birinci faktöre ait Cronbach Alpha değeri .75; ikinci faktöre ait Cronbach Alpha değeri ise .41 olarak bulunmuştur. Ölçeğin toplam alfa iç tutarlılık katsayıs1 .65'dir.

Ebeveynlik Stratejileri Ölçeğine ait geçerlik ve güvenirlik çalışması bulguları: Ölçekte öğretim teknikleri ile ilgili toplam 17 madde bulunmaktadır. Bu kısım iki aşamalı olup, ilk aşamada ebeveynin son 4 hafta içinde bu öğretim tekniklerini kullanıp kullanmadığını 1'de 4'e kadar derecelendirmesi istenmektedir. Örneğin; "Çocuğumun cinsellik konusundaki sorularına cevap verdim". İkinci aşamada ise ebeveynin her bir durum için kendini ne kadar rahat/emin hissettiğini-o durum nadiren yaşansa ya da henüz yaşanmasa bile- 1'den (kesinlikle yapamam) 10'a (kesinlikle yaparım) kadar derecelendirmesi istenmektedir. Örneğin; Çocuğumun cinsellik konusundaki sorularına cevap verirken kendimi rahat/emin hissederim". Ölçeğin KMO testi katsayısı .91, Barlett küresellik testinin de manidar $\left(x^{2}=2651.196\right.$. $\left.s d=136 . p<0.01\right)$ olduğu belirlenmiştir. Örneklem yeterliliği karşılandıktan sonra temel bileşenler analizi varimax döndürme tekniği kullanılarak yapılan AFA sonucunda, öz değeri 1'den büyük olan 3 faktörlü yapı bir yapı elde edilmiştir. Özgün ölçekte maddeler tek bir faktör altında toplanırken bu çalışmada üç faktörlü bir yapı ortaya çıkmıştır. Maddelerin aldıkları faktör yükü ve varyans değerleri birinci faktör için 4.111 ve \% 24.18, ikinci faktör için 3.593 ve \% 21.13, üçüncü faktör içinse 2.720 ve $\% 15.99$ 'dur. Üç faktörde toplanan maddelerin açıkladığ 1 toplam varyans miktarı \% 61.318'dir. Birinci faktör altında 5, 6, 7, 10, 15, 16 ve 17. maddeler yer almaktadır ve "Ebeveyn Tutumu" olarak adlandırılmıştır. İkinci alt boyutta 1, 2, 3, 8 ve 12. maddeler yer almaktadır ve "İletişim" olarak adlandırılmıştır. Üçüncü alt boyutta 9, 11, 13 ve 14. maddeler yer almaktadır ve "Öğretim Yöntemi” olarak adlandırılmıştır. Ölçeğin ayırtedicilik seviyesi için hesaplanan madde toplam korelasyon katsayısı $0.204-0.782$ aralığında değişmektedir. Tüm maddelerin .20 üzerinde olması nedeniyle ölçülecek özelliği ayırt etmede yeterli olduğu söylenebilir. Faktörler ile ilgili maddeler arasında istatistiksel olarak anlamlı bir ilişkinin olup olmadığ $1 \mathrm{t}$ testi sonucunda ise anlamlı bir ilişki saptanmıştır. Elde edilen bulgulara ilişkin sonuçlar Tablo 2'de gösterilmiştir.

Tablo 2: Ebeveynlik Stratejileri Ölçeğine ait bulgular

\begin{tabular}{|c|c|c|c|c|c|c|c|}
\hline \multicolumn{2}{|c|}{ Maddeler } & f1 & $\mathrm{f} 2$ & f3 & $\begin{array}{l}\text { Madde toplam } \\
\text { korelasyonları }\end{array}$ & $\begin{array}{l}\text { Madde silinmesi } \\
\text { durumunda } \alpha \\
\text { değeri }\end{array}$ & $\mathrm{t}$ değeri \\
\hline \multirow{7}{*}{$\begin{array}{l}\text { Ebeveyn } \\
\text { Tutumu }\end{array}$} & md16 & .820 & & & .572 & .909 & $13.86^{*}$ \\
\hline & $\mathrm{md} 17$ & .759 & & & .543 & .910 & $12.65^{*}$ \\
\hline & $\mathrm{md} 10$ & .745 & & & .534 & .910 & $12.18^{*}$ \\
\hline & $\mathrm{md} 7$ & .684 & & & .723 & .904 & $16.85^{*}$ \\
\hline & md15 & .649 & & & .602 & .908 & $12.49^{*}$ \\
\hline & md6 & .535 & & & .624 & .907 & $13.40^{*}$ \\
\hline & $\mathrm{md} 5$ & .460 & & & .557 & .909 & $9.76^{*}$ \\
\hline \multirow{5}{*}{ İletişim } & md1 & & .829 & & .609 & .908 & $13.93 *$ \\
\hline & $\mathrm{md} 3$ & & .794 & & 643 & .907 & $13.82 *$ \\
\hline & $\mathrm{md} 2$ & & .673 & & 647 & .907 & $14.20^{*}$ \\
\hline & md8 & & .656 & & .700 & .905 & $15.45^{*}$ \\
\hline & $\mathrm{md} 12$ & & .570 & & .782 & .902 & $17.40^{*}$ \\
\hline \multirow{5}{*}{$\begin{array}{l}\text { Öğretim } \\
\text { Yöntemi }\end{array}$} & md11 & & & .781 & .530 & .910 & $14.77^{*}$ \\
\hline & $\mathrm{md} 13$ & & & .768 & .585 & .908 & $15.81 *$ \\
\hline & md4 & & & .758 & .204 & .919 & $7.21 *$ \\
\hline & md14 & & & .512 & .602 & .908 & $12.45^{*}$ \\
\hline & md9 & & & .486 & .588 & .908 & $10.76^{*}$ \\
\hline \multicolumn{2}{|c|}{$\begin{array}{c}\text { Açıklanan varyans }(\%) \\
\text { Toplam }=\% 61.318\end{array}$} & 24.18 & 21.13 & 15.99 & & & \\
\hline
\end{tabular}

www.turkishstudies.net/education 
AFA sonucu tespit edilen 3 faktörlü yapının doğrulanması amacıyla Doğrulayıcı Faktör Analizi (DFA) uygulanmıştır. Modele ilişkin faktör yükleri 0.42 (madde 9) ile 0.83 (madde 8) arasında değişmektedir ve bütün faktör yükleri istatistiksel olarak anlamlıdır. DFA ile sınanan modelin uyum indeksleri incelendiğinde, ki-kare değerinin serbestlik derecesine oranının $\left(\mathrm{x}^{2} / \mathrm{df}=3.968\right) 5^{\prime}$ 'in altında kabul edilebilir bir düzeyde olduğu görülmüştür. Diğer uyum indeksleri incelendiğinde, RMSEA $=0.09 \quad(0.05<$ RMSEA $<0.10) \quad$ kabul edilebilir uyum, GFI $=0.90$ $(0.90<\mathrm{GFI}<0.95)$ kabul edilebilir uyum, $\mathrm{CFI}=0.95(0.95<\mathrm{CFI}<1)$ iyi uyum ve $\mathrm{AGFI}=0.85$ $(0.85<\mathrm{AGFI}<0.90)$ kabul edilebilir uyum gösterdiği görülmektedir.

Ebeveynlik davranışları ve öz-yeterlikleriyle ilgili iç tutarlılık katsayıları ise; birinci faktör için $\alpha=.85$ ve $\alpha=.85$; ikinci faktör için $\alpha=.87$ ve $\alpha=.90$; üçüncü faktör için $\alpha=.78$ ve $\alpha=.75$ olarak hesaplanmıştır. Anketin toplam alfa iç tutarlılık katsayısı .91'dir.

Ebeveyn Öz-Değerlendirme Ölçeğine ait geçerlik ve güvenirlik çalışması bulguları: Ölçekte 4 madde bulunmaktadır. Ölçeğin KMO testi katsayısı .71. Barlett küresellik testinin de manidar $\left(x^{2}=411.808 . s d=6 . p<0.01\right)$ olduğu belirlenmiştir. Faktör analizi sonucunda, öz değeri 1'den büyük olan tek faktörlü yapının faktör değeri 2.435 ve açıkladığı varyans değeri \% 60.87 çıkmıştır. Ölçeğin ayırtedicilik seviyesi için hesaplanan madde toplam korelasyon katsayısı 0.3910.676 aralığında değişmektedir. Tüm maddelerin .20 üzerinde olması nedeniyle ölçülecek özelliği ayırt etmede yeterli olduğu söylenebilir. Faktörler ile ilgili maddeler arasında istatistiksel olarak anlamlı bir ilişkinin olup olmadığı t testi sonucunda ise anlamlı bir ilişki saptanmıştır. Elde edilen verilere iliş̧kin sonuçlar Tablo 3'te gösterilmiştir.

Tablo 3: Ebeveyn Öz-Değerlendirme Ölçeğine ait bulgular

\begin{tabular}{|c|c|c|c|c|c|}
\hline \multicolumn{2}{|c|}{ Maddeler } & \multirow{2}{*}{$\begin{array}{l}\mathrm{f} 1 \\
.827\end{array}$} & \multirow{2}{*}{$\begin{array}{c}\begin{array}{c}\text { Madde toplam } \\
\text { korelasyonlar1 }\end{array} \\
.606\end{array}$} & \multirow{2}{*}{$\begin{array}{c}\begin{array}{c}\text { Madde silinmesi } \\
\text { durumunda } \alpha \text { değeri }\end{array} \\
.691\end{array}$} & \multirow{2}{*}{$\frac{t \text { değeri }}{14.44^{*}}$} \\
\hline & $\mathrm{md} 1$ & & & & \\
\hline Ebeveyn Öz- & $\mathrm{md} 2$ & .876 & .676 & .644 & $17.56^{*}$ \\
\hline \multirow{2}{*}{ Değerlendirme } & $\mathrm{md} 3$ & .809 & .627 & .663 & $11.57 *$ \\
\hline & $\mathrm{md} 4$ & .573 & .391 & .808 & $5.76^{*}$ \\
\hline \multicolumn{2}{|c|}{$\begin{array}{c}\text { Açıklanan varyans (\%) } \\
\text { Toplam=\% } 60.87\end{array}$} & 60.87 & & & \\
\hline
\end{tabular}

AFA sonucu tespit edilen tek faktörlü yapının doğrulanması amacıyla Doğrulayıcı Faktör Analizi (DFA) uygulanmıştır. Modele ilişkin faktör yükleri 0.34 (madde 4) ile 0.92 (madde 2) arasında değişmektedir ve bütün faktör yükleri istatistiksel olarak anlamlıdır. DFA ile sınanan modelin uyum indeksleri incelendiğinde, ki-kare değerinin serbestlik derecesine oranının $\left(\mathrm{x}^{2} / \mathrm{df}=0.25\right)$ 3'ün altında iyi uyum olduğu görülmüştür. Diğer uyum indeksleri incelendiğinde, RMSEA $=0.01(0<$ RMSEA $<0.05)$ iyi uyum, GFI $=0.99(0.95<\mathrm{GFI}<1)$ iyi uyum, CFI $=0.98$ $(0.95<\mathrm{CFI}<1)$ iyi uyum ve $\mathrm{AGFI}=0.99(0.90<\mathrm{AGFI}<1)$ iyi uyum gösterdiği görülmektedir. Kurulan modelin güvenirliğini incelemek amacıyla Cronbach alfa değeri hesaplanmış, iç tutarlılık katsayısı .76 bulunmuştur.

Ebeveynlerin Cinsel Ĕgitimin Önemi ile İlgili Görüşleri Ölçeğine ait geçerlik ve güvenirlik çalışması bulguları: Ölçekte 6 madde bulunmaktadır. Ölçeğin KMO testi katsayısı .85. Barlett küresellik testinin de manidar $\left(x^{2}=719.994\right.$. sd $\left.=15 . p<0.01\right)$ olduğu belirlenmiştir. Faktör analizi sonucunda, öz değeri 1'den büyük olan tek faktörlü yapının faktör değeri 3.359 ve açıkladığ 1 varyans değeri \% 55.982 çıkmıştır. Ölçeğin ayırtedicilik seviyesi için hesaplanan madde toplam korelasyon katsayısı $0.428-0.657$ aralığında değişmektedir. Tüm maddelerin .20 üzerinde olması nedeniyle ölçülecek özelliği ayırt etmede yeterli olduğu söylenebilir. Faktörler ile ilgili maddeler arasında istatistiksel olarak anlamlı bir ilişkinin olup olmadığ 1 testi sonucunda ise anlamlı bir ilişki saptanmıştır. Elde edilen verilere ilişskin sonuçlar Tablo 4’te gösterilmiştir. 


\begin{tabular}{|c|c|c|c|c|c|}
\hline \multicolumn{6}{|c|}{ Tablo 4: Ebeveynlerin Cinsel Eğitim ile ilgili Görüşleri Ölçeğine ait bulgular } \\
\hline \multicolumn{2}{|c|}{ Maddeler } & f1 & $\begin{array}{l}\text { Madde toplam } \\
\text { korelasyonlar1 }\end{array}$ & $\begin{array}{c}\text { Madde silinmesi } \\
\text { durumunda } \alpha \text { değeri }\end{array}$ & t değeri \\
\hline & md1 & .798 & .653 & .781 & $14.84^{*}$ \\
\hline Ebeveynlerin & $\mathrm{md} 2$ & .789 & .638 & .784 & $12.83 *$ \\
\hline Cinsel Eğitimin & $\mathrm{md} 3$ & .807 & .657 & .781 & $12.70 *$ \\
\hline Önemi ile ilgili & md4 & .771 & .648 & .778 & $13.82 *$ \\
\hline \multirow[t]{2}{*}{ Görüşleri } & md5 & .742 & .619 & .786 & $12.84 *$ \\
\hline & md6 & .552 & .428 & .845 & $8.10^{*}$ \\
\hline \multicolumn{2}{|c|}{$\begin{array}{l}\text { Açıklanan varyans }(\%) \\
\text { Toplam }=\% 55.98\end{array}$} & 55.98 & & & \\
\hline
\end{tabular}

AFA sonucu tespit edilen tek faktörlü yapının doğrulanması amacıyla Doğrulayıcı Faktör Analizi (DFA) uygulanmıștır. Modele ilișkin faktör yükleri 0.46 (madde 6) ile 0.76 (madde 1) arasında değişmektedir ve bütün faktör yükleri istatistiksel olarak anlamlıdır. DFA ile sınanan modelin uyum indeksleri incelendiğinde ki-kare değerinin serbestlik derecesine oranının $\left(\mathrm{x}^{2} / \mathrm{df}=3.109\right) 5^{\prime}$ 'in altında kabul edilebilir bir düzeyde olduğu görülmüştür. Diğer uyum indeksleri incelendiğinde, $\mathrm{RMSEA}=0.08 \quad(0.05<\mathrm{RMSEA}<0.10)$ kabul edilebilir uyum, GFI $=0.97$ $(0.95<\mathrm{GFI}<1)$ iyi uyum, CFI $=0.98(0.95<\mathrm{CFI}<1)$ iyi uyum ve $\mathrm{AGFI}=0.93(0.90<\mathrm{AGFI}<1)$ iyi uyum gösterdiği görülmektedir. Kurulan modelin güvenirliğini incelemek amaciyla Cronbach alfa değeri hesaplanmış. iç tutarlılık katsayısı .82 bulunmuştur.

Cinsel Eğitim Programı Müfredatı Hakkında Ebeveynlerin Görüşleri Ölçeğine ait geçerlik ve güvenirlik çalışması bulguları: Ölçekte 22 madde bulunmaktadır. Anketin KMO testi katsayısı .92. Barlett küresellik testinin de manidar $\left(\mathrm{x}^{2}=4183.734 . \mathrm{sd}=231 . \mathrm{p}<0.01\right)$ olduğu belirlenmiştir. Örneklem yeterliliği karșlandıktan sonra temel bileșenler analizi varimax döndürme tekniği kullanılarak yapılan AFA sonucunda, öz değeri 1'den büyük olan 3 faktörlü yapı bir yap1 elde edilmiştir. Özgün ölçekte maddeler tek bir faktör altında toplanırken bu çalışmada üç faktörlü bir yap1 ortaya çıkmıştır. Maddelerin aldıkları faktör yükü ve varyans değerleri birinci faktör için 6.063 ve \% 27.56, ikinci faktör için 4.147 ve \% 18.85, üçüncü faktör içinse 2.739 ve $\% 12.45$ 'dur. Üç faktörde toplanan maddelerin açıkladığ 1 toplam varyans miktarı \% 58.860'dır. Birinci faktör altında $1,3,4,5,6,7,8,9,10,12,15$ ve 21 . maddeler yer almaktadır ve "Tutum Geliştirme" olarak adlandırılmıştır. İkinci alt boyutta $2,11,13,14,16,17$ ve 22 . maddeler yer almaktadır ve "İletişim Kurma" olarak adlandırılmıştır. Üçüncü alt boyutta 18,19 ve 20 . maddeler yer almaktadır ve "Davranış" olarak adlandırılmıştır. Ölçeğin ayırtedicilik seviyesi için hesaplanan madde toplam korelasyon katsayısı 0.392-0.704 aralığında değişmektedir. Tüm maddelerin .20 üzerinde olması nedeniyle ölçülecek özelliği ayırt etmede yeterli olduğu söylenebilir. Faktörler ile ilgili maddeler arasında istatistiksel olarak anlamlı bir ilişkinin olup olmadığ $1 \mathrm{t}$ testi sonucunda ise anlamlı bir ilişki saptanmıştır. Elde edilen bulgulara ilişsin sonuçlar Tablo 5 'te gösterilmiştir.

Tablo 5: Ebeveyn Programına Yönelik Algılar ile ilgili bulgular

\begin{tabular}{llllllll}
\hline Maddeler & f1 & f2 & f3 & $\begin{array}{l}\text { Madde toplam } \\
\text { korelasyonları }\end{array}$ & $\begin{array}{c}\text { Madde silinmesi } \\
\text { durumunda } \alpha \\
\text { değeri }\end{array}$ & t değeri \\
\hline
\end{tabular}




\begin{tabular}{|c|c|c|c|c|c|c|c|}
\hline \multirow{12}{*}{$\begin{array}{l}\text { Tutum } \\
\text { Geliştirme }\end{array}$} & $\mathrm{md} 4$ & .759 & & & .598 & .891 & $15.64^{*}$ \\
\hline & md 15 & .752 & & & .585 & .891 & $13.99 *$ \\
\hline & md7 & .726 & & & .443 & .895 & $9.86^{*}$ \\
\hline & md9 & .705 & & & .612 & .891 & $14.44^{*}$ \\
\hline & $\mathrm{md} 12$ & .686 & & & .575 & .891 & $14.49 *$ \\
\hline & md1 & .632 & & & .541 & .891 & $13.15^{*}$ \\
\hline & md6 & .627 & & & .632 & .890 & $15.35^{*}$ \\
\hline & md5 & .620 & & & .655 & .890 & $15.96^{*}$ \\
\hline & $\mathrm{md} 21$ & .602 & & & .616 & .890 & $13.34 *$ \\
\hline & $\mathrm{md} 8$ & .580 & & & .616 & .891 & $14.41 *$ \\
\hline & $\mathrm{md} 10$ & .552 & & & .569 & .891 & $13.23 *$ \\
\hline & $\mathrm{md} 3$ & .498 & & & .571 & .891 & $13.36^{*}$ \\
\hline \multirow{7}{*}{$\begin{array}{l}\text { İletişim } \\
\text { Kurma }\end{array}$} & md16 & & .759 & & .592 & .890 & $13.20^{*}$ \\
\hline & md17 & & .722 & & .545 & .891 & $10.98^{*}$ \\
\hline & $\mathrm{md} 2$ & & .591 & & .618 & .890 & $13.93 *$ \\
\hline & md11 & & .580 & & .704 & .888 & $17.11^{*}$ \\
\hline & md14 & & .577 & & .674 & .889 & $16.00 *$ \\
\hline & $\mathrm{md} 13$ & & .497 & & .507 & .892 & $10.95^{*}$ \\
\hline & $\mathrm{md} 22$ & & .420 & & .396 & .895 & $6.61 *$ \\
\hline \multirow{3}{*}{ Davranış } & md19 & & & .941 & .424 & .900 & $22.44^{*}$ \\
\hline & $\operatorname{md} 18$ & & & .913 & .473 & .898 & $20.51^{*}$ \\
\hline & md20 & & & .896 & .392 & .902 & $17.95^{*}$ \\
\hline \multicolumn{2}{|c|}{$\begin{array}{c}\text { Açıklanan varyans }(\%) \\
\text { Toplam }=\% 55.860\end{array}$} & 27.56 & 18.85 & 12.45 & & & \\
\hline
\end{tabular}

AFA sonucu tespit edilen 3 faktörlü yapının doğrulanması amacıyla Doğrulayıcı Faktör Analizi (DFA) uygulanmıştır. Modele ilişkin faktör yükleri 0.37 (madde 17) ile 0.91 (madde 18) arasında değişmektedir ve bütün faktör yükleri istatistiksel olarak anlamlıdır. DFA ile sınanan modelin uyum indeksleri incelendiğinde, ki-kare değerinin serbestlik derecesine oranının $\left(\mathrm{x}^{2} / \mathrm{df}=2.774\right) 5^{\prime}$ 'in altında kabul edilebilir bir düzeyde olduğu görülmüştür. Diğer uyum indeksleri incelendiğinde, $\mathrm{RMSEA}=0.07 \quad(0.05<\mathrm{RMSEA}<0.10) \quad$ kabul edilebilir uyum, GFI $=0.91$ $(0.90<\mathrm{GFI}<0.95)$ kabul edilebilir uyum, $\mathrm{CFI}=0.97(0.95<\mathrm{CFI}<1)$ iyi uyum ve $\mathrm{AGFI}=0.88$ $(0.85<\mathrm{AGFI}<0.90)$ kabul edilebilir uyum gösterdiği görülmektedir. Kurulan modelin boyutlarının güvenirliklerini incelemek amacıyla Cronbach alfa değerleri hesaplanmıştır. Elde edilen sonuçlara göre, birinci faktöre ait Cronbach alfa değeri .91; ikinci faktöre ait Cronbach alfa değeri ise .82; üçüncü faktöre ait Cronbach alfa değeri ise .92 olarak bulunmuştur. Anketin toplam alfa iç tutarlılık katsayis1 .90 'dir.

\section{Sonuç, Tartışma ve Öneriler}

Bu çalışmada, Morawska ve arkadaşları (2015) tarafından geliştirilen Ebeveynlik ve Çocuk Cinselliği Anketinin Türk ebeveynlerden oluşan bir grup üzerinde geçerlik ve güvenirliği incelenmiştir. Anketin İngilizce ve Türkçe formları arasında yüksek düzeyde pozitif ve anlamlı ilişki olduğu saptanmıştır $(\mathrm{r}=.80 . \mathrm{r}=.80 . \mathrm{r}=.82 . \mathrm{r}=.81 . \mathrm{r}=.83 . \mathrm{r}=.65 ; \mathrm{p}<0.05)$. Bu bulgular dikkate alınarak anketin Türkçe formunun özgün form ile eş değer olduğu söylenebilir.

Anket içeriğinde yer alan toplamda 5 farklı ölçeğin yapı geçerliğini incelemek üzere AFA'da çıkan yapının sınanması için DFA uygulanmıştır. AFA sonuçlarına göre, 3 ölçeğin özgün ölçeği yapısı ile örtüşen tek faktörlü bir yapı oluşturduğu görülmüss, 2 ölçek de ise özgün ölçeğin yapısından farklı olarak üç faktörlü bir yapı elde edilmiştir. DFA ile sınanan modellerin ki-kare derecesinin serbestlik derecesine oranları ve uyum indeksleri dikkate alındığında; Ebeveynlerin Cinsel Eğitim Bilgi ve Deneyimleri Ölçeğinin iyi uyum gösterdiği, Ebeveynlik Stratejileri Ölçeğinin kabul edilebilir düzeyde uyum, Ebeveyn Öz-Değerlendirme Ölçeğinin iyi uyum, 
Ebeveynlerin Cinsel Eğitimin Önemi ile İlgili Görüşleri Ölçeğinin kabul edilebilir düzeyde uyum, Cinsel Eğitim Programı Müfredatı Hakkında Ebeveynlerin Görüşleri Ölçeğinin kabul edilebilir düzeyde uyum gösterdiği görülmüştür. Özgün ölçeklerin iç tutarlılık katsayıları (sırasılyla; $\alpha=.77$, $\alpha=.90$ ve $\alpha=.95 . \alpha=.78, \alpha=.65, \alpha=.94$ ) dikkate alındığında, bu çalışmada ölçeklerin iç tutarlılık katsayıları güvenirliğin yeterli olduğuna işaret etmektedir (sırasıyla; $\alpha=.65, \alpha=.91$ ve $\alpha=.90, \alpha=.76$, $\alpha=.82, \alpha=.90)$.

Sonuç olarak, geçerlik ve güvenirlik çalışması yapılan anketin çocuğun cinsel gelişiminde ebeveynlik rolleri üzerine araştırma yapmak isteyen uzmanlar tarafından kullanılabileceği düşünülmektedir. Anket, gelecekte farklı örneklem gruplarında uygulanarak sonuçları değerlendirilebilinir.

\section{Kaynakça}

Bayhan. P. ve Artan. İ. (2004). Çocuk Gelişim ve Eğitimi. İstanbul: Morpa Yayınları.

Büyüköztürk. Ş. (2006). Sosyal bilimler için veri analizi el kitabı. Ankara: PegemA Yayıncılık. https://doi.org/10.14527/9789756802748

Byers. E. S.. Sears. H.A. veWeaver. A.D. (2008). Parents' reports of sexualcommunicationwithchildren in kindergartentograde 8. Journal of MarriageandFamily. 70 (1). 86-96.

Çalışandemir. F. Bencik. S ve Artan. İ. (2008) Çocukların cinsel eğitimi: geçmişten günümüze bir bakış Ĕgitim ve Bilim. Cilt 33. Sayı 150s:14-27

Eliküçük. A. ve Sönmez. S.(2011). 6 Yaş çocuklarının cinsel gelişim ve eğitimiyle ilgili ebeveyn görüşlerinin incelenmesi Aile ve Toplum.12(7). 45-62. https://doi.org/10.26449/sssj.1814

Erbil. N.. Orak. E.. Bektaş. A.. E.. ve Birkök. M. C. (2010) Anneler cinsel eğitim konusunda ne biliyor. kızlarına ne kadar cinsel eğitim veriyor?Uluslararası İnsan Bilimleri Dergisi. 7(1). 367-383. https://doi.org/10.17152/gefad.377516

Erkuş. A. (2012). Psikolojide ölçme ve ölçek geliştirme-I: Temel kavramlar. Ankara: Pegem Akademi Yayınları. https://doi.org/10.14527/9786053643111

Eroğlu.K. ve Gölbaşı. Z.(2005). Cinsel eğitimde ebeveynlerin yeri: ne yapıyorlar. ne yaşıyorlar? Atatürk Üniversitesi Hemşirelik Yüksekokulu Dergisi. 8(2). 12-21.

Gözüm. S. ve Aksayan. S. (2002). Kültürlerarası ölçek uyarlaması için rehber I: Ölçek uyarlama aşamaları ve dil uyarlaması. Hemşirelik Araştırma Dergisi. 4(1). 9-14. https://doi.org/10.26650/fnjn397481

Gürsoy. E., Gençalp, N.S. (2010) Cinsel Sağlık Eğitiminin Önemi.Aile ve Toplum. 11(6). 29-36.

Kalaycı. Ş. (2005). SPSS uygulamalı çok değişkenli istatistik teknikleri. Ankara: Asil Yayın Dağıtım.

Konur H. (2006).Dört - altı yaşları arasında çocuğu olan anne - babalara verilen "Cinsel Ĕ̈itim Programı"nın cinsel şelişim ve cinsel eğitim konusundaki bilgilerine etkisinin incelenmesi. Yayınlanmamış yüksek lisans tezi. Gazi Üniversitesi Eğitim Bilimleri Enstitüsü. Ankara https://doi.org/10.17152/gefad.377516

Morawska. A.. Walsh. A.. Grabski. M.veFletcher. R. (2015). Parental confidence and preferences for communicating with their child about sexuality. Sex Education. 15(3). 235-248. https://doi.org/10.1080/14681811.2014.996213 
Özdamar. K. (2004). Paket programlar ile istatistiksel veri analizi I. 5.Baskı. Eskişehir: Kaan Yayınlar1

Pluhar. E.. Jennings. T. veDilorio. C. (2006). Getting an early start: Communication about sexuality among mothers and children 6-10 yearsold. Journal of HIV/AIDS Prevention in Children\& Youth. 7 (1). 7-35.

Sümer. N. (2000). Yapısal eşitlik modelleri: Temel kavramlar ve örnek uygulamalar. Türk Psikoloji Yazıları. 3 (6) 49 -74.

Tuğrul.B. Artan İ.(2001) Çocukların Cinsel Eğitimi İle İlşili Anne Görüşlerinin İncelenmesi Hacettepe Üniversitesi Eğitim Fakültesi Derşisi 20: 141 - 149 